\title{
Kinetics and secretion of placental growth hormone around parturition
}

Jens Fuglsang, Puk Sandager, Niels Møller ${ }^{1}$, Sanne Fisker ${ }^{1}$, Hans Ørskov ${ }^{1}$ and Per Ovesen ${ }^{2}$

Gynecological/Obstetrical Research laboratory Y, Aarhus University Hospital, Skejby Sygehus, DK-8200 Aarhus N, Denmark, ${ }^{1}$ Medical Research Laboratories, Aarhus University Hospital, Aarhus Kommunehospital, DK-8000 Aarhus C, Denmark and ${ }^{2}$ Gynecological/Obstetrical Department, Aarhus University Hospital, Skejby Sygehus, DK-8200 Aarhus N, Denmark

(Correspondence should be addressed to J Fuglsang; Email: Fuglsang@ki.au.dk)

\begin{abstract}
Objective: During pregnancy, placental growth hormone (PGH) is secreted into the maternal circulation, replacing pituitary GH. It is controversial whether PGH levels decline during vaginal birth. After placental expulsion, PGH is eliminated from the maternal blood. GH binding protein (GHBP) and body mass index (BMI) influence GH kinetics, but their impact on PGH kinetics is unknown. The present study was undertaken to define the kinetics of PGH during vaginal delivery and Caesarian section and to relate these kinetics to GHBP and BMI.

Design: A short term, prospective cohort study.

Methods: Twelve women had repeated blood samples drawn during vaginal delivery. From 26 women undergoing planned Caesarian delivery (CS) repeated blood samples were withdrawn before, during and after the CS, allowing PGH half-life determination.

Results: During vaginal delivery, median PGH values did not change before expulsion of the placenta, although individual fluctuations were seen. Clearance of PGH from the maternal circulation was best described by a two-compartment model. The initial half-life of serum PGH was (mean \pm s.D.) 5.8 $\pm 2.4 \mathrm{~min}$, and the late half-life was (median) $87.0 \mathrm{~min}$ (range: $25.1-679.6 \mathrm{~min}$ ). The late halflife was correlated to the pre-gestational BMI $(r=0.39, P=0.047)$, but not to the serum GHBP concentration.

Conclusions: Serum PGH did not decrease significantly during vaginal delivery. Elimination of PGH fitted a two-compartment model, with an estimated initial half-life of $5.8 \mathrm{~min}$. The late phase serum half-life of PGH was related to BMI, suggesting a role for maternal fat mass in PGH metabolism.
\end{abstract}

European Journal of Endocrinology $154449-457$

\section{Introduction}

Human placental growth hormone (PGH) is secreted from the placental syncytiotrophoblast into the maternal circulation, whereas no PGH is found in the fetal circulation $(1,2)$. Secretion is evident early in the first trimester (3), and PGH gradually replaces pituitary growth hormone $(\mathrm{GH})$, which is stabilised at very low, but still detectable levels, in the last half of pregnancy $(2,4,5)$. Maximum levels of PGH approach acromegalic levels of $\mathrm{GH}$ around gestational weeks 35-37 (3-6). Pulsatile secretion is not a feature of PGH (7), justifying single blood sample evaluation of PGH levels. It is controversial whether PGH levels decline in the last weeks of pregnancy. In recent studies, no significant decrease was observed $(6,8,9)$; however, the most recent study reported decreasing values from week 37 onwards, which was most pronounced in the group of mothers carrying the smallest fetuses (3). In addition, serum PGH levels have been reported to decline during labour $(4,9)$.

Only 13 amino acid residues constitute the difference between PGH and GH (10), and both GH and PGH are transported by the high affinity GH-binding protein (GHBP), which, in turn, influences the half-life of GH (11-13). In addition, body mass index (BMI) influences both GHBP levels and GH turnover (14). The half-life of PGH has been estimated in a few small series with direct $(9)$ or indirect $(2,15)$ measurements of serum PGH concentrations, but none of these studies has been large enough to take the impact of GHBP or body weight into account.

The physiology of PGH is largely undetermined, although it is surmised that it mimics GH physiology. Studies of PGH elimination may provide new insights into basal PGH metabolism and uncover potential 
factors influencing PGH turnover. By comparison with GH physiology, such studies may unravel the discrepancies between the two growth hormones and lead to a better understanding of PGH function.

In this report, we describe the changes in $\mathrm{PGH}$ during and after vaginal delivery and Caesarian section. Special attention has been paid to define (i) whether serum PGH levels decline during labour, (ii) the kinetics of $\mathrm{PGH}$ and (iii) the interrelationship between PGH and factors of potential importance for its turnover.

\section{Materials and methods}

In the present study, forty-two healthy women with singleton pregnancies were included, 12 women delivering vaginally and 30 admitted for elective Caesarian section (CS). All participants gave informed consent. The protocol was approved by the Regional Ethical Committee for Aarhus County (journal no. 2002 0312). The Danish Data Protection Agency, Copenhagen, approved the collection of data (journal no. 2003-41-3011).

In one woman delivering vaginally, betamethasone and indomethacin were administered in week 33 due to suspected preterm delivery; however, pregnancy continued to week 40. In all other women, pregnancies did not require intervention. Systemic medication was noted in two CS participants; one was using cetirizine due to allergy and one patient was using mesalazine sporadically, but not within the last 10 days before CS. One participant had had an (unremarkable) oral glucose tolerance test performed in pregnancy. No participant had glucosuria diagnosed at routine examinations by their general practitioner and midwife during pregnancy. Characteristics of the participants are given in Table 1.

\section{Vaginal delivery}

Of the 12 participants, 9 had spontaneous labour and three underwent induction of labour by rupture of the membranes.

According to the protocol, participants had nonfasting venous blood samples withdrawn during labour at cervical dilatation of less than $3 \mathrm{~cm}, 3-6 \mathrm{~cm}$, 6-9 cm, and at full dilation. Finally, a blood sample was withdrawn one hour post partum.

\section{Caesarian section}

Thirty women with singleton pregnancies were enrolled in the study. Elective Caesarian section (CS) was performed due to breech presentation $(n=4)$, former CS $(n=6)$, former lesion of the anal sphincter $(n=8)$, or on maternal request $(n=12)$. Participants had non-fasting blood samples taken on the day of hospitalisation. On the day of CS, participants had fasting blood samples taken after placement of an intravenous cannula in the forearm. Blood samples were withdrawn just before removal of the placenta $(\mathrm{t}=0 \mathrm{~min})$, and then at $10,20,30,40,50,60,90,120$ and $240 \mathrm{~min}$. Participants were fasted, but were not deprived of drink (free access to tap water), until $\mathrm{t}=120 \mathrm{~min}$. The i.v. cannula was kept patent with saline, and for each blood sample the first $\mathrm{ml}$ was discarded. According to the study protocol, blood sampling during CS was aborted if estimated bleeding $>500 \mathrm{ml}$ occurred. This was the case for two participants. In two patients, difficulties with the intravenous catheter prompted cessation of blood sampling. These four patients were included in the analyses of nonfasting PGH levels, but they were excluded from half-life analyses. Thus, determinations of PGH half-life took place in 26 participants, who had a median estimated bleeding volume of $300 \mathrm{ml}$ (range: $150-500 \mathrm{ml}$ ).

Table 1 Characteristics for the two groups of participants and their newborns.

\begin{tabular}{|c|c|c|c|}
\hline & Vaginal delivery $(n=12)$ & Caesarian section $(n=30)$ & $P$ \\
\hline Age (years) & $31.8 \pm 6$ & $33 \pm 4$ & NS \\
\hline Parity & $1(0-4)$ & $1(0-3)$ & NS \\
\hline Height (cm) & $170 \pm 4$ & $169 \pm 6$ & NS \\
\hline Pre-gestational weight (kg) & $70.1 \pm 13.1$ & $66.5 \pm 11.5$ & NS \\
\hline Pre-gestational BMI $\left(\mathrm{kg} / \mathrm{m}^{2}\right)$ & $24.0(19.3-36.8)$ & $22.4(18.4-33.0)$ & NS \\
\hline Weight gain in pregnancy $(\mathrm{kg})$ & $20.0(11.6-26)^{a}$ & $14.0(4.0-29.0)$ & NS \\
\hline Gestational age at delivery - weeks & $40.3 \pm 1.1$ & $39.0 \pm 0.4$ & $P<0.001$ \\
\hline - days & $282 \pm 8$ & $273 \pm 3$ & \\
\hline Pregnancy obtained after ART (no.) & 1 & 1 & \\
\hline Newborns female/male (no.) & $6 / 6$ & $20 / 10$ & NS \\
\hline Birth weight $(\mathrm{g})$ & $3688 \pm 384$ & $3528 \pm 399$ & NS \\
\hline Birth weight z-score & $0.2 \pm 0.9$ & $0.3 \pm 0.8$ & NS \\
\hline Birth length (cm) & $52 \pm 2$ & $52 \pm 2$ & NS \\
\hline Ponderal index $\left(\mathrm{kg} / \mathrm{m}^{3}\right)$ & $26.7 \pm 2.1^{b}$ & $25.2 \pm 2.1$ & $P=0.05$ \\
\hline Placenta weight $(\mathrm{g})$ & $670 \pm 85^{c}$ & $733 \pm 130$ & NS \\
\hline
\end{tabular}

Data are given as means \pm S.D. for normally distributed data, otherwise as median and range in parentheses.

${ }^{a}$ Data were available for 7 subjects only; ${ }^{b} n=11 ;{ }^{c} n=10$. ART, assisted reproductive techniques; NS, not significant. 
All CSs were elective and were performed using spinal analgesia. Isotonic saline was administered during establishment of spinal analgesia and during the CS. Most participants received antacida on the morning before CS. After birth, intravenous syntocinon was administered, and rectal naproxen was given postoperatively. Antibiotics were administered according to routine guidelines.

Blood samples for the study of the growth hormone axis before and after parturition were drawn from participants undergoing CS (16).

\section{Biochemical analyses}

The blood was allowed to clot, then cooled in an ice bath until centrifugation, and serum was pipetted off and stored at $-80^{\circ} \mathrm{C}$. All hormone samples were determined in duplicate. Serum PGH was measured with a commercially available solid phase immunoradiometric assay (PGH IRMA, BC1017, Biocode, Liege, Belgium). Cross-reactivity with pituitary $\mathrm{GH}$ was below $0.001 \%$, according to the manufacturer. In our setting, both the intra- and interassay coefficients of variation were $<6 \%$. The minimum detectable concentration was calculated as the mean of 10 replicate determinations of the 0 -standard $+3 \times$ s.D., and was lower than $0.4 \mu \mathrm{g} / \mathrm{l}$. Serum total GHBP was determined in an in-house immunofunctional assay as earlier described (17). In our laboratory, this assay has an intra-assay coefficient of variation of $3.4 \%$ and an interassay coefficient of variation of $12 \%$ at $0.563 \mathrm{nmol} / \mathrm{l}$ and $6.3 \%$ at $1.4 \mathrm{nmol} / \mathrm{l}$. Serum total GH was measured by Delfia TRIFMA specific to the $22 \mathrm{kDa}$ pituitary GH (Wallac, Turku, Finland). The detection limit was lower than $0.03 \mu \mathrm{g} / \mathrm{l}$ and the intra- and interassay coefficients of variation were $2 \%$ and $3.2 \%$ respectively.

Albumin in serum was measured using a Vitros 950 analyzer (Ortho-Clinical Diagnostics, Johnson \& Johnson Medical Devices, Birkeroed, Denmark).

\section{Calculations and statistical analyses}

The gestational age at delivery was calculated from the last menstrual cycle and confirmed by first trimester ultrasound scan measurement; alternatively ultrasound scan measurements alone were used when appropriate. The gestational age is given in weeks, and reflects the number of completed weeks. Expected human pregnancy length is 40 weeks plus 0 days ( $=280$ days). The birth weight z-scores were calculated as (observed - expected birth weight)/s.D. of expected birth weight. Expected birth weights were derived from birth weights from a normal cohort of 32573 live-births in non-diabetic mothers with a singleton pregnancy delivering from 01.03.1997 to 28.02.2004 at Skejby Hospital, Aarhus N, Denmark.
The half-life of serum PGH was determined assuming a double exponential elimination of $\mathrm{PGH}$ following the formula: serum PGH concentration $=$

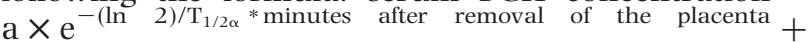
$\mathrm{b} \times \mathrm{e}^{-(\ln 2) / \mathrm{T}_{1 / 2 \beta} \times \text { minutes after removal of the placenta }}$. In the following, $\mathrm{T}_{1 / 2 \alpha}$ will be denoted $\mathrm{T}_{1 / 2 \text { init }}$ and $\mathrm{T}_{1 / 2 \beta}$ will be denoted $\mathrm{T}_{1 / 2 \text { late }}$. The assumption of a double exponential decay was justified with $\mathrm{R}^{2}$-values (median and range) of 0.996 (0.972-0.999) for curve fitting.

Calculations of the placental PGH release at steady state were based on the equation: metabolic clearance rate $=V_{d} \times k$, where $V_{d}$ is the distribution volume and $\mathrm{k}=(\ln 2) / \mathrm{T}_{1 / 2 \text { init. }}$. The $\mathrm{V}_{\mathrm{d}}$ was estimated from previous studies $(13,14,18,19)$ and set to $5000 \mathrm{ml}$.

Approximated values for the serum concentrations of free and bound PGH were calculated from the law of mass action as exemplified by Barsano \& Baumann (20), assuming a stoichiometric ratio of 1:1 in growth hormone binding to GHBP at serum levels of GHBP (21), a molecular weight of $\mathrm{GH}$ and non-glycosylated PGH of $22000 \mathrm{Da}(22,23)$, and an affinity constant $\left(K_{\mathrm{a}}\right)$ of GHBP of $0.91 \mathrm{l} / \mathrm{nmol}(24)$.

Data were log transformed where appropriate to obtain normality. Unless otherwise stated, normally distributed data are given as means \pm S.D., non-normally distributed data are given as median and range. Repeated measurements ANOVA with the Bonferroni $t$-test for multiple comparisons were used to compare hormone concentrations over time. The Pearson product moment correlation coefficient was used for testing correlations. A $P$ value $<0.05$ was considered significant. All statistics were performed using the software SigmaStat 2.03 (SPSS Inc., Chicago, IL, USA) Curve fitting was performed in Sigmaplot 8.02 (SPSS Inc.).

\section{Results}

Table 1 gives the characteristics for the two groups of participants. Data for the two groups of participants and their newborns were similar, except for a higher gestational age at delivery in the vaginal delivery group, who also tended to give birth to babies with a slightly higher ponderal index $(P=0.05)$.

\section{Vaginal delivery}

Non-fasting serum PGH was (median) 10.1 (range: 7.7-35.3) $\mu \mathrm{g} / \mathrm{l}$ upon admittance to the delivery ward (Fig. 1). This was significantly lower than the nonfasting serum PGH levels in women admitted for elective CS $(19.9 \mu \mathrm{g} / \mathrm{l}$, range: $8.2-92.4 ; \quad P=0.033)$, despite a higher gestational age (282 (269-297) days vs $274(264-278)$ days; $P<0.001)$ and similar BMI. Unexpectedly, large fluctuations in serum PGH values were observed during the progression of labour; however no consistent changes in PGH values were observed, especially no significant decrease was 

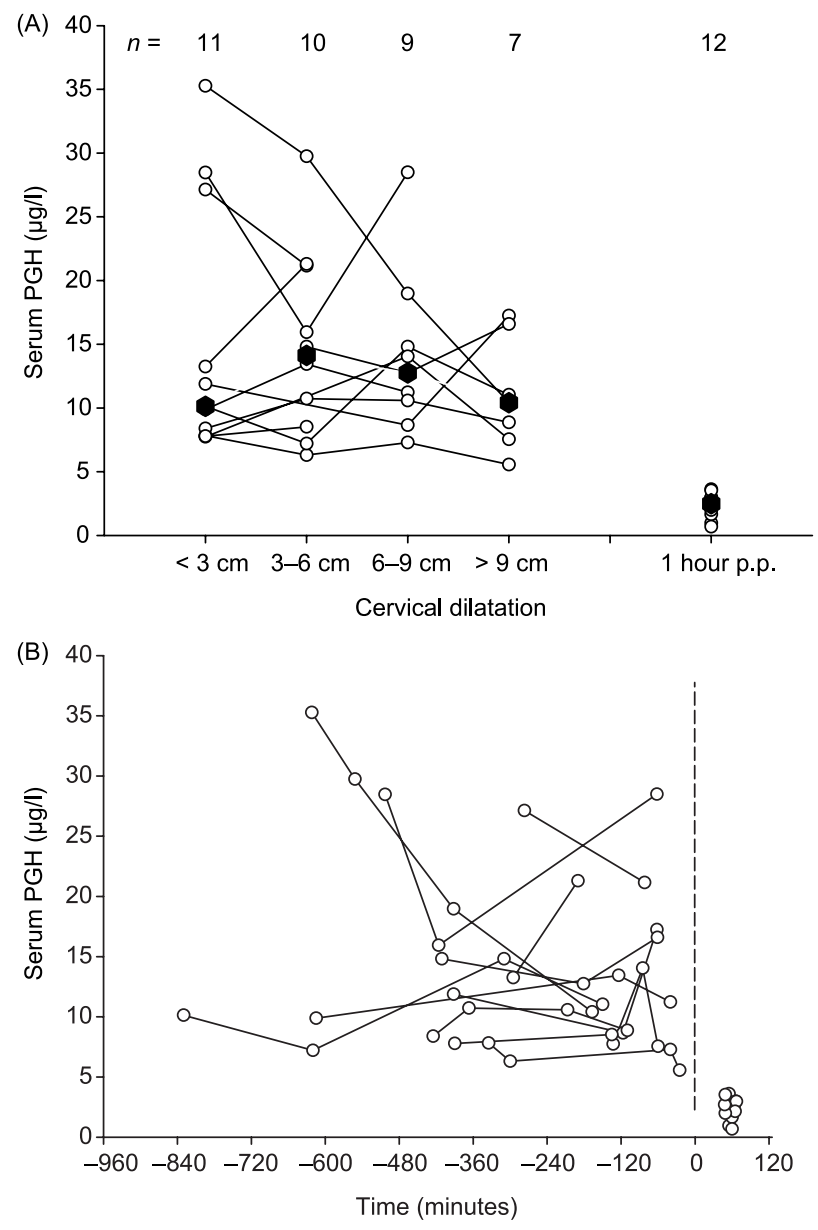

Figure 1 Serum PGH during vaginal delivery in 12 healthy women. (A) Serum PGH in relation to the various stages of cervical dilatation. Open circles indicate individual values, solid hexagons indicate the median. The number of individuals represented at each time point is indicated at the top. The time intervals between samples were 150 (35-490) min from a cervical dilation of $<3 \mathrm{~cm}$ to $3-6 \mathrm{~cm}$, then $160(85-354) \mathrm{min}, 76(15-225) \mathrm{min}$, and the post partum (p.p.) samples were obtained $58(48-67) \mathrm{min}$ after placental expulsion. Placentas were delivered within $11 \mathrm{~min}$ after delivery of the baby. (B) Serum PGH in relation to the time of expulsion of the placenta. The dotted vertical line (time $=0 \mathrm{~min}$ ) denotes delivery of the placenta.

observed, regardless of stage of labour (Fig. 1A) or duration of labour (Fig. 1B). As expected, very low levels of PGH were detected $1 \mathrm{~h}$ after expulsion of the placenta $(P<0.001)$.

\section{Caesarian section}

Serum GHBP Before CS, fasting serum GHBP levels averaged $1.75 \pm 0.55 \mathrm{nmol} / \mathrm{l}$. Serum GHBP levels were stable during and after CS.

Growth hormones Before CS, $49.5 \pm 12.6 \%$ (range: $18.2-73.3 \%$ ) of PGH was bound to GHBP at a PGH level of $24.0 \mathrm{ng} / \mathrm{ml}$ (range: 10.2-87.2).
Serum PGH decreased (median 40.2\% (range: $0.0-60.2 \%) ; P<0.001$ ) in the time interval from fasting blood samples to the withdrawal of blood at $t=0$ before removal of the placenta (median $49 \mathrm{~min}$, range 18-167 min). As this could be a consequence of the infusion of saline before the establishment of spinal analgesia, analysis of serum albumin was performed. In the same samples, serum albumin decreased (median $21.0 \%(-2.2-34.9 \%)$ ), and changes in serum albumin were not significantly correlated to changes in PGH $(r=0.07, P=0.7)$. Thus simple dilution alone failed to explain the entire concentration change in PGH before removal of the placenta. The decrease in PGH was not correlated to the time span between blood samples. A slight and non-significant increase to $53.1 \pm 9.7 \%$ in the proportion bound was observed during this decrease in PGH values $(P=0.094$, ANOVA $)$.

After removal of the placenta, serum PGH values declined rapidly (Fig. 2). In a semilogarithmic plot, a two compartment elimination curve was implied. Therefore, the serum half-life was calculated for an initial period, $T_{1 / 2 \text { init }}$, and in the late phase, $T_{1 / 2 \text { late }}$. Figure 2A gives an example of an elimination curve. In the initial phase, $\mathrm{PGH}$ disappeared rapidly from the maternal circulation with a median $\mathrm{T}_{1 / 2 \text { init }}$ of 5.8 $\pm 2.4 \mathrm{~min} \quad$ (range 3.1-11.4 min), (Fig. 2B,C). Approximately $67 \%$ of the baseline PGH concentration was cleared after $30 \mathrm{~min}$ and $88 \%$ after $2 \mathrm{~h}$ (Fig. 2C). In the late phase, serum PGH disappeared at a much slower rate, giving a $\mathrm{T}_{1 / 2 \text { late }}$ value of (median) $87.0 \mathrm{~min}$ (25.1-679.6 min). Sixty minutes after removal of the placenta, the GHBP-bound fraction of PGH had increased to $60.6 \pm 6.7 \% \quad(P<0.001$, ANOVA).

Assuming a distribution volume of 5 litres, the metabolic clearance rate was calculated to be $693 \mathrm{ml} / \mathrm{min}$. Hence, in a steady state condition maintaining PGH at $22 \mu \mathrm{g} / \mathrm{l}(1 \mathrm{nmol} / \mathrm{l})$ for the last 6 weeks of pregnancy, a total of $0.92 \mathrm{~g}$. (i.e. approximately $1 \mathrm{~g}$ ) of PGH will be secreted from the placenta to the maternal circulation.

As expected, fasting levels of pituitary $\mathrm{GH}$ were low before CS, $0.11 \mu \mathrm{g} / \mathrm{l}$ (0.02-0.54). After removal of the placenta, serum GH levels were continuously low, and only minor fluctuations were observed.

\section{Correlation studies}

Correlation coefficients for variables related to PGH metabolism are given in Table 2. The two half-lives tended to correlate $(r=0.36, P=0.069)$. Neither $\mathrm{T}_{1 / 2 \text { init }}$ nor $\mathrm{T}_{1 / 2 \text { late }}$ was associated to GHBP levels; however, the $\mathrm{T}_{1 / 2 \text { late }}$ correlated to the pre-pregnant BMI $(r=0.39, P=0.047)$ (Fig. 3).

Before birth, an inverse correlation was observed between PGH and GHBP levels $(r=-0.55$, $P=0.005)$. 

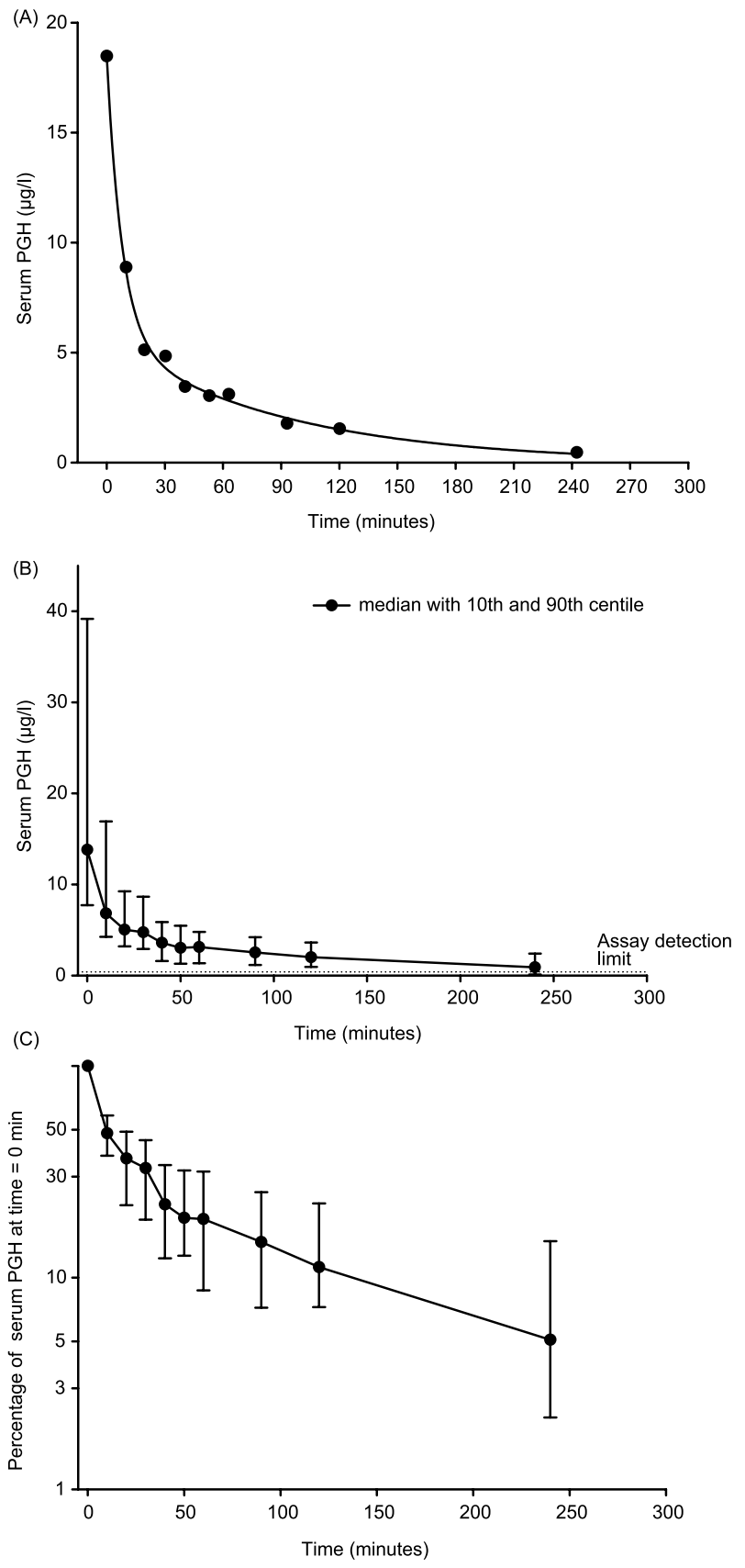

Figure 2 Serum PGH during Caesarian section. (A) An example of the disappearance of $\mathrm{PGH}$ from maternal serum after elective Caesarian section. The presented elimination curve followed a two-compartment elimination curve with a fit of $r^{2}=0.997$. For the entire group of participants, the fit was (median) 0.996 (range 0.972-0.999). In this example, the elimination curve was characterised by the formula: serum $\mathrm{PGH}=12.91 \times \mathrm{e}^{-0.1260 \times \text { time }}+5.589 \times \mathrm{e}^{-0.0109 \times \text { time }}$, giving a $T_{1 / 2 \text { init }}$ of $5.5 \mathrm{~min}$ and a $T_{1 / 2 \text { late }}$ of $63.4 \mathrm{~min}$. In (B), absolute values for serum PGH concentrations are displayed $(n=26)$. The dotted line represents the minimum detectable PGH concentration of the assay. In (C), the relative decrease in serum $\mathrm{PGH}$ levels over time is shown. The PGH level at time $=0$ min has been set to $100 \%$. Note the log scale of the $y$-axis. Data in B and $\mathrm{C}$ are given as median with 10th and 90th centile.
The bound fraction of PGH at CS was not correlated to either of the two half-lives, to the pre-pregnant BMI, or to BMI at CS.

\section{Discussion}

The major findings of the present study are that PGH displays two-compartment elimination kinetics which are associated with BMI. An initial fast plasma elimination of PGH with half-lives of $\sim 5-6 \mathrm{~min}$ and a second phase with half-lives of $\sim 1.5 \mathrm{~h}$ were observed. No changes in PGH levels were observed during vaginal delivery, although baseline levels were low in the normal range.

PGH is secreted by the syncytiotrophoblast solely to the maternal circulation $(1,2)$. It is found in high concentrations during the last half of pregnancy, and at the same time pituitary GH is virtually absent in plasma $(4,5)$. The regulation and physiology of $\mathrm{PGH}$ is far from being understood, but the secretion of $\mathrm{PGH}$ is described as non-pulsatile (7). Pituitary GH has a well-known impact upon adipose tissue metabolism $(25,26)$, and PGH binds equally as well as $\mathrm{GH}$ to GHBP (11), which is the extracellular part of the GH receptor. Lipolytic effects of $\mathrm{PGH}$ have been demonstrated using rodent adipocytes (27).

The pattern of PGH levels during the last weeks and days of pregnancy is controversial. Cross-sectional and longitudinal studies have suggested a slight decrease in PGH (3-5), especially in women giving birth to children with lower birth weights (3). At birth, abruptly decreasing values at the onset of labour were noted by Mirlesse and colleagues $(4,28)$. In contrast, Coutant et al. could not demonstrate any difference in PGH levels in weeks 35-40 compared with early labour (8). We observed that in women delivering vaginally, serum PGH levels upon admittance to the delivery ward were somewhat lower than the PGH levels in women admitted for elective CS, despite a slightly higher gestational age in the former group. Birth weight z-scores and BMI were comparable; hence no obvious explanation for the lower PGH levels in early labour was found. In a recent paper, one woman delivering vaginally was observed to have decreasing values of serum PGH shortly before delivery (9), and $\mathrm{Wu}$ et al. found no explicit decline in $\mathrm{PGH}$ values up to $30 \mathrm{~min}$ before parturition in two patients (6). The present findings thus resemble these latter observations, as no significant changes in serum PGH values were observed during the course of vaginal delivery. In particular, none of the participants demonstrated markedly decreased PGH levels during labour as previously described (4), even at full cervical dilatation. These findings do not exclude the possibility that some reorganisation of placental physiology occurs during or shortly before vaginal delivery, but it appears that at least a basal secretory tone of $\mathrm{PGH}$ is maintained 
Table 2 Correlation coefficients between variables in univariate analyses.

\begin{tabular}{|c|c|c|c|c|c|c|}
\hline & $T_{1 / 2 \text { init }}$ & $T_{1 / 2 \text { late }}^{a}$ & $\mathrm{PGH}^{\mathrm{a}}$ & GHBP & BMI pre-pregnant $^{a}$ & $\mathrm{BMI}$ at CS \\
\hline$T_{1 / 2 \text { init }}$ & - & & & & & \\
\hline $\mathrm{T}_{1 / 2 \text { late }}^{\mathrm{a}}$ & $0.36 \rrbracket$ & - & & & & \\
\hline $\mathrm{PGH}^{\mathrm{a}}$ & -0.00 & -0.05 & - & & & \\
\hline GHBP & 0.18 & 0.26 & $-0.55^{\star \star}$ & - & & \\
\hline BMI pre-pregnant ${ }^{\mathrm{a}}$ & 0.15 & $0.39^{\star}$ & 0.03 & $0.44^{*}$ & - & \\
\hline $\mathrm{BMI}$ at CS & 0.10 & 0.31 & 0.08 & 0.28 & $0.90^{\star \star *}$ & - \\
\hline
\end{tabular}

a Data were log transformed before analysis. CS; caesarian section; $T_{1 / 2 \text { init }}, T_{1 / 2}$ in the first phase of PGH disappearance from the blood; $T_{1 / 2 \text { late, }} T_{1 / 2}$ in the second phase. $n=24-28$.

${ }^{\star} P<0.05 ;{ }^{* *} P<0.01 ;{ }^{* \star *} P<0.001 ;$ ๆ $P=0.069$.

even during advanced labour. Altogether, serum or placental samples obtained in relation to vaginal delivery may not be representative of third trimester hormone secretion, and this should be taken into account in future study designs.

Shortly before removal of the placenta at CS, a decrease in PGH was observed and this decrease was not explained by simple haemodilution. At least three mechanisms may contribute to the observed decrease in PGH levels. First, peripheral vasodilation may cause vascular 're-entry' influx of extravascular fluids with different PGH content. Secondly, sympathetic/ adrenergic tone at CS may influence PGH liberation from the placenta. Thirdly, maternal blood flow may be redirected as a consequence of the preparatory procedures for CS. Regarding the latter, all newborns had normal umbilical cord $\mathrm{pH}$, indicating that the blood supply to the placenta was sufficient for fetal aerobic metabolism.

Most studies of GH half-life describe elimination after $\mathrm{GH}$ infusion, finding a half-life of total GH of around 15-20 min following mono-exponential decay curves

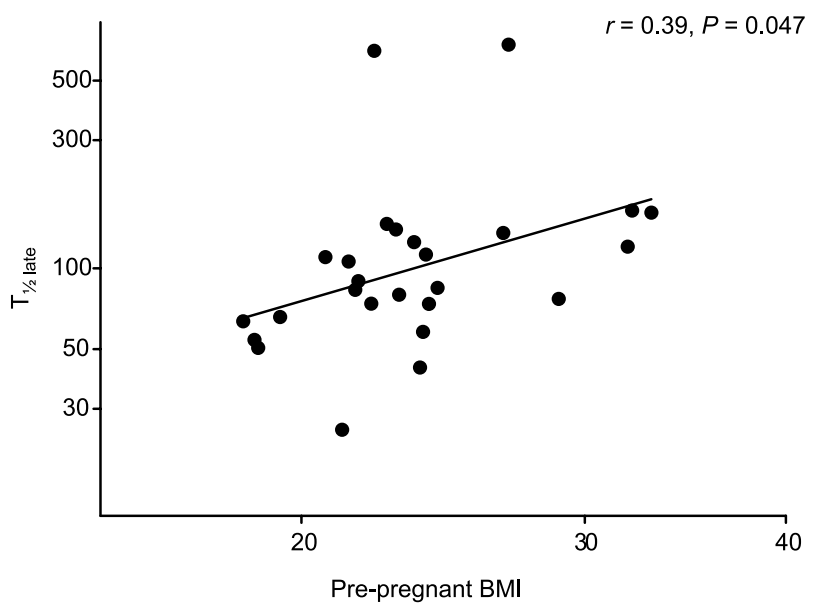

Figure 3 Late phase serum PGH half-life vs pre-pregnant BMI $(n=26)$. Note the logarithmic scales on the axes. Exclusion of the two outliers only strengthened the association $(r=0.54$, $P=0.006)$.
(13, 18, 25, 29). Alterations in $\mathrm{GH}$ levels induce minor changes in the half-life, suggesting saturation of elimination pathways at high concentrations $(18,29)$. Rather than being influenced by differing PGH levels, the present results suggest that the elimination of PGH is dissociated into two phases following a two-compartment model. Studies of GH metabolism sometimes assume one-compartment models to facilitate calculations; however two-compartment models following double-exponential decay curves have been recognised for both $\mathrm{GH}$ and $\mathrm{GH}-\mathrm{GHBP}$ complexes (30-32), and also for the analogous human placental lactogen (hPL), which apparently has an early halflife of less than 13 min (33).

Previously, indirect estimates of PGH levels at parturition have indicated that the elimination of $\mathrm{PGH}$ was a rapid process $(2,15)$. We observed a mean half-life of PGH in the initial phase of $\sim 5-6 \mathrm{~min}$, which is somewhat lower than the earlier observations in four women by Lonberg et al. (9), who assumed a mono-exponential decay of PGH from the maternal circulation within the first $30 \mathrm{~min}$ and found a half-life of 13-14 min. Actually, very similar results are obtained from the present data if calculations are based on the assumption of a mono-exponential decay in the first 30 min (data not shown).

A theoretical half-life of free $\mathrm{GH}$ of 2-12 min was found by Veldhuis et al. when no GHBP was present (13). Similarly, a half-life of $3.5 \mathrm{~min}$ was estimated for the free $\mathrm{GH}$ fraction in infusion studies at a total halflife of $13 \mathrm{~min}$ (34). In our setting, rapid plasma elimination independent of GHBP levels was observed at calculated levels of bound PGH averaging 50\%. The bound value depends on the GHBP measurements, and different GHBP assays may provide differing GHBP values (17); however, regardless of assay, a substantial proportion of PGH will be bound, even in the third trimester. Also, the high levels of PGH justify the assumption of 1:1 complexing between PGH and GHBP $(21,35)$. Pregnancy is a long-lasting condition, allowing the maternal organism sufficient time to adapt to high PGH levels, and PGH kinetics at birth may therefore be different from the elimination of high levels of $\mathrm{GH}$ after acute infusion. Adenomectomy in acromegalic subjects may be a comparable situation to CS with 
regard to cessation of high growth hormone secretion of long duration. In such situations, however, intraoperative $\mathrm{GH}$ half-lives are slightly higher than halflives found in acute studies $(36,37)$. Hence, among growth hormone analogues, plasma elimination of the placental variants $\mathrm{PGH}$ and hPL appears to be described most accurately by two-compartment kinetics, different from most observations on GH elimination from plasma. Furthermore, a rapid half-life of PGH predominates at physiological levels of GHBP and is independent hereof. The mechanism behind the rapid elimination of $\mathrm{PGH}$ is unclear. Intuitively, PGH clearance takes place through $\mathrm{GH}$ receptors (GHRs), although the importance of GHRs in plasmatic clearance of pituitary GH has been questioned (18). Tissue expression of GHRs during pregnancy is virtually unknown but could have an impact on PGH kinetics.

At a pituitary GH level of $25 \mu \mathrm{g} / \mathrm{l}$, as much as $46 \%$ of the total metabolic clearance of $\mathrm{GH}$ may be renal in non-pregnant subjects (19), and renal GH clearance depends on BMI and fat mass (38). During pregnancy, renal blood flow and glomerular filtration rate increase as does the maternal fat mass, and, hence, renal clearance could be a substantial contributor to PGH elimination. Evidently, the observed rapid half-life was not caused by PGH clearance, even though the placenta could be a potential influence on plasmatic PGH elimination in pregnancy.

The initial phase of rapid PGH elimination is followed by a phase in which a larger proportion of PGH is placed extravascularly or is bound to GHBP, the latter also demonstrated here. We attempted to investigate whether GHBP had an influence on PGH half-lives, but we were unable to demonstrate such a relationship. Instead, the pre-gestational BMI was associated with the late phase half-life and with GHBP levels at birth. As for the BMI at birth, this parameter not only reflects the maternal fat mass but also the presence of the pregnancy product and no significant association to $\mathrm{PGH}$ metabolism was observed. Altogether, the positive associations between pre-gestational BMI and both PGH metabolism and GHBP levels suggest that adipose tissue may interact with PGH metabolism, possibly involving the GHRs (39).

Most studies, although not all (31), point to an effect of GHBP on GH kinetics $(12,13,29,30)$. GHBP is the extracellular domain of the GHR, but it has not been clarified whether circulating GHBP mirrors tissue GHR status (40). Notwithstanding, the majority of GHBP is presumed to derive from hepatic and adipose tissue. Local GHBP accumulation could tend to withhold PGH, decrease PGH exchange with serum, and form inert complexes when PGH cross-binds GHBP and GHRs.

Such situations are compatible with longer half-lives at high BMI and are expected to be most influential at low levels of circulating PGH. Thereby, effects of PGH, e.g. lipolysis (27), would be down-regulated and this could be expedient when the caloric supply to the placenta is assured otherwise, for example, by frequent or large caloric intakes. Supporting this, decreased PGH levels are observed with increasing BMI (3, 41, 42). Although the latter association was not demonstrated here, indirect evidence in terms of a negative association between PGH and GHBP levels was found, confirming the results of McIntyre et al. (43).

The PGH assay uses antibodies raised against the non-glycosylated hormone; however, a glycosylated variant has been recognised (23). It is not known whether glycosylation affects assay PGH detection or PGH kinetics. Finally, it should be stressed that the late half-life of PGH is not influenced by any sudden occurrence of pituitary $\mathrm{GH}$ in the maternal circulation, as the level of $\mathrm{GH}$ was constant at very low levels during the observation period.

In conclusion, PGH levels fluctuated during advanced labour and mean levels were unchanged. Serum PGH appears initially to be eliminated at a very rapid rate with a half-life of $\sim 5-6 \mathrm{~min}$. Later, at lower levels, a half-life of $\sim 1.5 \mathrm{~h}$ was observed, showing some relation to the maternal BMI. Assuming steady-state or near steady-state concentrations of PGH in the last weeks of pregnancy, the short half-life suggests a high turnover rate of $\mathrm{PGH}$. Elimination pathways for PGH remain to be clarified.

\section{Acknowledgements}

The staff at the gynaecological/obstetrical surgical and anaesthesiology units willingly offered their assistance. The skilful technical assistance of Mrs Inga Bisgaard, Mrs Merete Møller and Mrs Kirsten Nyborg is kindly acknowledged. Data for the reference cohort of more than 32000 women were kindly provided by the Perinatal Epidemiological Research Unit at Skejby Hospital, Aarhus N. Associate professor Preben Jakobsen at the Department of Pharmacology, Aarhus University, is thanked for advice on the pharmacokinetic analyses.

This study was supported with grants from the Clinical Institute at Aarhus University Hospital (Skejby Hospital, Aarhus N), the 'Holger Rabitz and wife Doris May, born Phillips, grant', the 'Konsul Johannes Fogh-Nielsens og Fru Ella Fogh-Nielsens Legat' and from the Danish Health Research Council (grant no. 9600822; Aarhus University-Novo Nordisk Centre for Research in Growth and Regeneration).

\section{References}

1 Jara CS, Salud AT, Bryant-Greenwood GD, Pirens G, Hennen G \& Frankenne F. Immunocytochemical localization of the human growth hormone variant in the human placenta. Journal of Clinical Endocrinology and Metabolism 198969 1069-1072.

2 Frankenne F, Closset J, Gomez F, Scippo ML, Smal J \& Hennen G. The physiology of growth hormones (GHs) in pregnant women 
and partial characterization of the placental GH variant. Journal of Clinical Endocrinology and Metabolism 198866 1171-1180.

3 Chellakooty M, Vangsgaard K, Larsen T, Scheike T, Falck-Larsen J, Legarth J, Andersson AM, Main KM, Skakkebaek NE \& Juul A. A longitudinal study of intrauterine growth and the placental growth hormone (GH)-insulin-like growth factor-I axis in maternal circulation: association between placental $\mathrm{GH}$ and fetal growth. Journal of Clinical Endocrinology and Metabolism 200489 384-391.

4 Mirlesse V, Frankenne F, Alsat E, Poncelet M, Hennen G \& EvainBrion D. Placental growth hormone levels in normal pregnancy and in pregnancies with intrauterine growth retardation. Pediatric Research 199334 439-442.

5 Caufriez A, Frankenne F, Englert Y, Golstein J, Cantraine F, Hennen G \& Copinschi G. Placental growth hormone as a potential regulator of maternal IGF-I during human pregnancy. American Journal of Physiology 1990258 E1014-E1019.

6 Wu Z, Bidlingmaier M, Friess SC, Kirk SE, Buchinger P, Schiessl B \& Strasburger CJ. A new nonisotopic, highly sensitive assay for the measurement of human placental growth hormone: development and clinical implications. Journal of Clinical Endocrinology and Metabolism $2003 \mathbf{8 8} 804-811$.

7 Eriksson L, Frankenne F, Eden S, Hennen G \& Von Schoultz B. Growth hormone 24-h serum profiles during pregnancy - lack of pulsatility for the secretion of the placental variant. British Journal of Obstetrics and Gynecology 198996 949-953.

8 Coutant R, Boux DC, Douay O, Mathieu E, Rouleau S, Beringue F, Gillard P, Limal JM \& Descamps P. Relationships between placental $\mathrm{GH}$ concentration and maternal smoking, newborn gender, and maternal leptin: possible implications for birth weight. Journal of Clinical Endocrinology and Metabolism 200186 4854-4859.

9 Lonberg U, Damm P, Andersson AM, Main KM, Chellakooty M, Lauenborg J, Skakkebaek NE \& Juul A. Increase in maternal placental growth hormone during pregnancy and disappearance during parturition in normal and growth hormone-deficient pregnancies. American Journal of Obstetrics and Gynecology 2003188 247-251.

10 Seeburg PH. The human growth hormone gene family: nucleotide sequences show recent divergence and predict a new polypeptide hormone. DNA $19821239-249$.

11 Baumann G, Davila N, Shaw MA, Ray J, Liebhaber SA \& Cooke NE. Binding of human growth hormone (GH)-variant (placental GH) to GH-binding proteins in human plasma. Journal of Clinical Endocrinology and Metabolism 199173 1175-1179.

12 Hansen TK, Fisker S, Hansen B, Sorensen HH, Christiansen JS, Jorgensen JO \& Orskov H. Impact of GHBP interference on estimates of $\mathrm{GH}$ and $\mathrm{GH}$ pharmacokinetics. Clinical Endocrinology $200257779-786$.

13 Veldhuis JD, Johnson ML, Faunt LM, Mercado M \& Baumann G. Influence of the high-affinity growth hormone $(\mathrm{GH})$-binding protein on plasma profiles of free and bound $\mathrm{GH}$ and on the apparent half-life of GH. Modeling analysis and clinical applications. Journal of Clinical Investigation 199391 629-641.

14 Hansen TK, Jorgensen JO \& Christiansen JS. Body composition and circulating levels of insulin, insulin-like growth factorbinding protein-1 and growth hormone $(\mathrm{GH})$-binding protein affect the pharmacokinetics of GH in adults independently of age. Journal of Clinical Endocrinology and Metabolism 200287 2185-2193.

15 Eriksson L, Frankenne F, Eden S, Hennen G \& Von Schoultz B. Growth hormone secretion during termination of pregnancy. Further evidence of a placental variant. Acta Obstetricia et Gynaecologica Scandinavica $198867549-552$.

16 Fuglsang J, Sandager P, Møller N, Fisker S, Frystyk J \& Ovesen P. Peripartum maternal and fetal ghrelin, growth hormones, IGFs and insulin interrelations. Clinical Endocrinology 2005. In Press.

17 Fisker S, Frystyk J, Skriver L, Vestbo E, Ho KK \& Orskov H. A simple, rapid immunometric assay for determination of functional and growth hormone-occupied growth hormone-binding protein in human serum. European Journal of Clinical Investigation 199626 $779-785$.
18 Veldhuis JD, Bidlingmaier M, Anderson SM, Evans WS, Wu Z \& Strasburger CJ. Impact of experimental blockade of peripheral growth hormone $(\mathrm{GH})$ receptors on the kinetics of endogenous and exogenous GH removal in healthy women and men. Journal of Clinical Endocrinology and Metabolism 200287 5737-5745.

19 Haffner D, Schaefer F, Girard J. Ritz E \& Mehls O. Metabolic clearance of recombinant human growth hormone in health and chronic renal failure. Journal of Clinical Investigation 199493 $1163-1171$.

20 Barsano CP \& Baumann G. Simple algebraic and graphic methods for the apportionment of hormone (and receptor) into bound and free fractions in binding equilibria; or how to calculate bound and free hormone? Endocrinology 1989124 1101-1106.

21 Baumann G, Lowman HB, Mercado M \& Wells JA. The stoichiometry of growth hormone-binding protein complexes in human plasma: comparison with cell surface receptors. Journal of Clinical Endocrinology and Metabolism $1994 \mathbf{7 8} 1113-1118$.

22 Frankenne F, Scippo ML, Van Beeumen J, Igout A \& Hennen G. Identification of placental human growth hormone as the growth hormone-V gene expression product. Journal of Clinical Endocrinology and Metabolism 199071 15-18.

23 Ray J. Jones BK, Liebhaber SA \& Cooke NE. Glycosylated human growth hormone variant. Endocrinology 1989125 566-568.

24 Barnard R, Quirk P \& Waters MJ. Characterization of the growth hormone-binding protein of human serum using a panel of monoclonal antibodies. Journal of Endocrinology 1989123 327-332.

25 Hansen TK. Pharmacokinetics and acute lipolytic actions of growth hormone. Impact of age, body composition, binding proteins, and other hormones. Growth Hormone and IGF Research $200212342-358$.

26 Norrelund H, Nair KS, Nielsen S, Frystyk J, Ivarsen P, Jorgensen JO, Christiansen JS \& Moller N. The decisive role of free fatty acids for protein conservation during fasting in humans with and without growth hormone. Journal of Clinical Endocrinology and Metabolism $2003 \mathbf{8 8} 4371-4378$.

27 Goodman HM, Tai LR, Ray J, Cooke NE \& Liebhaber SA. Human growth hormone variant produces insulin-like and lipolytic responses in rat adipose tissue. Endocrinology $1991 \quad 129$ $1779-1783$.

28 Evain-Brion D, Alsat E, Igout A, Frankenne F \& Hennen G. Placental growth hormone variant: assay and clinical aspects. Acta Paediatrica Suppl 1994399 49-51.

29 Hansen TK, Gravholt CH, Orskov H, Rasmussen MH, Christiansen JS \& Jorgensen JO. Dose dependency of the pharmacokinetics and acute lipolytic actions of growth hormone. Journal of Clinical Endocrinology and Metabolism 200287 4691-4698.

30 Baumann G, Amburn KD \& Buchanan TA. The effect of circulating growth hormone-binding protein on metabolic clearance, distribution, and degradation of human growth hormone. Journal of Clinical Endocrinology and Metabolism 198764 657-660.

31 Bright GM, Veldhuis JD, Iranmanesh A, Baumann G, Maheshwari H \& Lima J. Appraisal of growth hormone $(\mathrm{GH})$ secretion: evaluation of a composite pharmacokinetic model that discriminates multiple components of GH input. Journal of Clinical Endocrinology and Metabolism 199984 3301-3308.

32 Langendonk JG, Meinders AE, Burggraaf J, Frolich M, Roelen CA, Schoemaker RC, Cohen AF \& Pijl H. Influence of obesity and body fat distribution on growth hormone kinetics in humans. American Journal of Physiology 1999277 E824-E829.

33 Klopper A, Buchan P \& Wilson G. The plasma half-life of placental hormones. British Journal of Obstetrics and Gynaecology $1978 \mathbf{8 5}$ $738-747$.

34 Schaefer F, Baumann G, Haffner D, Faunt LM, Johnson ML, Mercado M, Ritz E, Mehls O \& Veldhuis JD. Multifactorial control of the elimination kinetics of unbound (free) growth hormone $(\mathrm{GH})$ in the human: regulation by age, adiposity, renal function, and steady state concentrations of GH in plasma. Journal of Clinical Endocrinology and Metabolism $19968122-31$.

35 Wada M, Uchida H, Ikeda M, Tsunekawa B, Naito N, Banba S, Tanaka E, Hashimoto Y \& Honjo M. The 20-kilodalton (kDa) 
human growth hormone (hGH) differs from the 22-kDa hGH in the complex formation with cell surface hGH receptor and hGHbinding protein circulating in human plasma. Molecular Endocrinology $199812146-156$.

36 van den Berg G, van Dulken H, Frolich M, Meinders AE \& Roelfsema F. Can intra-operative GH measurement in acromegalic subjects predict completeness of surgery? Clinical Endocrinology $19984945-51$.

37 Valdemarsson S, Ljunggren S, Cervin A, Svensson C, Isaksson A, Nordstrom CH \& Siesjo P. Evaluation of surgery for acromegaly: role of intraoperative growth hormone measurement? Scandinavian Journal of Clinical and Laboratory Investigation 200161 459-470.

38 Buijs MM, de Leeuw PW, Houben AJ, Kroon AA, Frolich M, Pijl H \& Meinders AE. Renal contribution to increased clearance of exogenous growth hormone in obese hypertensive patients. Journal of Clinical Endocrinology and Metabolism 200590 795-799.

39 Fisker S, Kristensen K, Rosenfalck AM, Pedersen SB, Ebdrup L, Richelsen B, Hilsted J, Christiansen JS \& Jorgensen JO. Gene expression of a truncated and the full-length growth hormone (GH) receptor in subcutaneous fat and skeletal muscle in GH-deficient adults: impact of GH treatment. Journal of Clinical Endocrinology and Metabolism $200186792-796$.

40 Amit T, Youdim MB \& Hochberg Z. Clinical review 112: does serum growth hormone $(\mathrm{GH})$ binding protein reflect human $\mathrm{GH}$ receptor function? Journal of Clinical Endocrinology and Metabolism $200085927-932$.

41 Chellakooty M, Skibsted L, Skouby SO, Andersson AM, Petersen JH, Main KM, Skakkebaek NE \& Juul A. Longitudinal study of serum placental GH in 455 normal pregnancies: correlation to gestational age, fetal gender, and weight. Journal of Clinical Endocrinology and Metabolism 200287 2734-2739.

42 Verhaeghe J, Pintiaux A, Van Herck E, Hennen G, Foidart JM \& Igout A. Placental GH, IGF-I, IGF-binding protein-1, and leptin during a glucose challenge test in pregnant women: relation with maternal body weight, glucose tolerance, and birth weight. Journal of Clinical Endocrinology and Metabolism 200287 2875-2882.

43 McIntyre HD, Serek R, Crane DI, Veveris-Lowe T, Parry A, Johnson S, Leung KC, Ho KK. Bougoussa M, Hennen G, Igout A. Chan FY, Cowley D, Cotterill A \& Barnard R. Placental growth hormone $(\mathrm{GH})$, GH-binding protein, and insulin-like growth factor axis in normal, growth-retarded, and diabetic pregnancies: correlations with fetal growth. Journal of Clinical Endocrinology and Metabolism 200085 1143-1150.

Received 26 September 2005

Accepted 21 December 2005 